\title{
STUDYING THE IMPROVEMENT OF TENSILE STRENGTH OF LOW ALLOY HIGH STRENGTH STEEL WELDS USING AN ECONOMICAL TECHNIQUE
}

\author{
Abdul Sameea Jasim Abdul Zehra Jilabi \\ sameeakilabi@gmail.com \\ Faculty of Materials Engineering/University of Babylon
}

\begin{abstract}
Low alloy steels are particularly used in manufacturing several parts in the heavy engineering industries, agricultural equipment and dies which may be subject to service failure, and thus may need to be repaired by one of the welding processes. The weldability of steels is determined by their sensitivity to cracks that can be prevented by the use of special welding procedures which are often expensive and difficult to use. Manual metal arc welding of low alloy high strength steels was done firstly, using a cheap electrode (OK 46.00), followed by the use of an economical technique which depends on coiling copper wires with different diameters around the cheap electrode. The expensive electrode (OK 73.68) was also used for comparison. Results showed an increase in the tensile strength (712 $\mathrm{MPa}$ ) and weld joint efficiency $(83.8 \%)$ when the expensive iron powder low hydrogen covering electrode (OK 73.68) was used. On the other hand, the tensile strength was decreased to $(206 \mathrm{MPa})$ and the weld joint efficiency to $(24.2 \%)$ when the cheap electrode (OK 46.00) was used. Coiling a $(0.6 \mathrm{~mm})$ dia. copper wire around the (OK 46.00) electrode increased the tensile strength and weld joint efficiency to (510 $\mathrm{MPa})$ and $(60 \%)$ respectively.
\end{abstract}

KEYWORDS: Low alloy high strength steel welds, tensile strength.

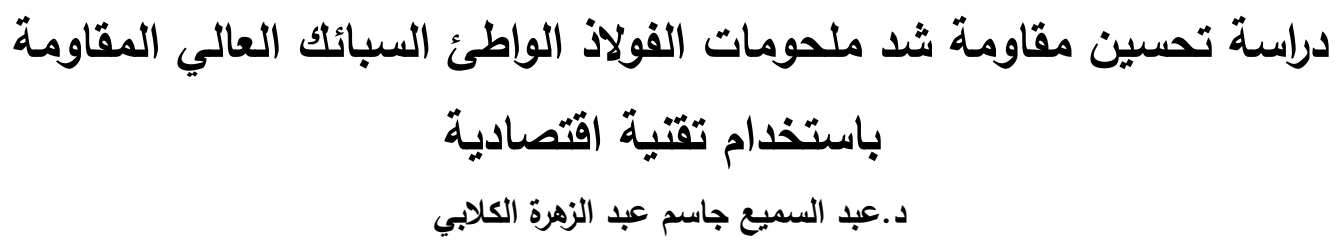

يستخدم الفولاذ الواطئ السبائك بشكل خاص في تصنيع الكثير من أجزاء المعدات الهنسية النقيلة والمعدات

الزراعية والقوالب والتي قد تكون عرضة للفشل اثثاء الخدمة، مما قد يتطلب الامر إصلاحها بواسطة احدى عمليات

اللحام. يتم تحديد قابلية لحام الفولاذ من خلال تحسسه للثقوق والتي يمكن الوقاية منها عن طريق استخدام إجراءات لحام

خاصة غالبا ما تكون مكلفة وصعبة الاستخدام. نم لحام الفولاذ الواطئ السبائك العالي المقاومة بطريقة القوس الكهربائي

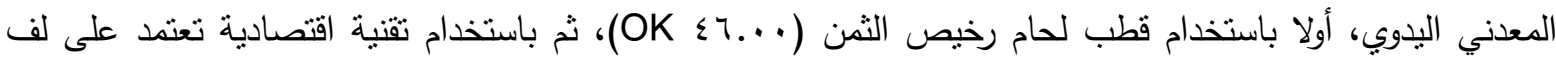

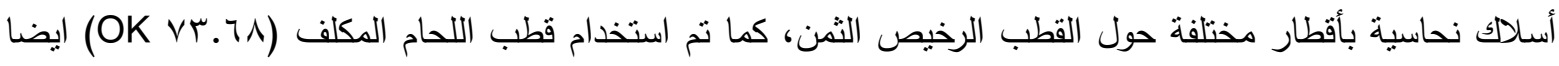




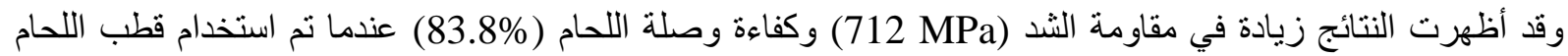

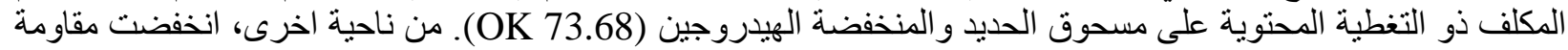

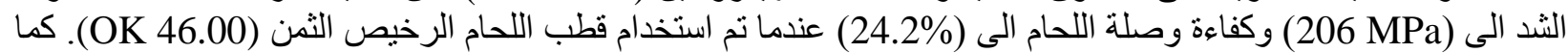
ان لف سلك نحاسي بقطر (6) (0.6 mm) حول قطب اللحام (OK 46.00) ادى الى زيادة قيمني مقاومة الثد وكفاءة وصلة اللحام

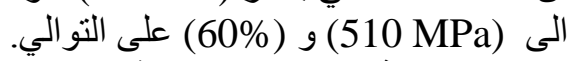
كلمات مفتاحية: ملحومات الفولاذ الواطئ السبائك العالي المقاومة، مقاومة الثد.

\section{INTRODUCTION}

Many alloying elements are typically added to steel with different weights such as chromium, nickel, vanadium, tungsten and cobalt. The elements of manganese, silicon, phosphorus and sulfur are also added with greater amounts than in carbon steels. The aim of these additions is to increase not only the strength but the thermal and corrosion resistances too, in addition to improving the hardenability, machinability and ductility. Low alloy high strength steels (LAHSS) are generally stronger than carbon steels but are slightly more expensive. These types of steels have many applications in the manufacture of gears, spindles, connecting rods, crankshafts, axles, springs, bearings and rollers in addition to manufacturing dies and many parts of the agricultural equipment [Bailey, 1972; Khanna, 1980]. These products may be subjected to failure during service, and their return to work may require to be repaired or maintained by one of the available fusion welding processes. The weldability of low alloy steels depends on the chemical composition (carbon and alloying elements) and hardenability. The hardenability increases with increasing the amounts of the carbon and alloying elements, and thus, increasing the difficulty of welding these types of steels. Therefore, there is a need for care and caution and for the use of special welding procedures to avoid the occurrence of hot and cold welding cracks in the weld zone and heat affected zone (HAZ). These cracks are considered the most significant and dangerous welding defects, where the weldability of steels is determined by their sensitivity to these cracks [Stuart, 1997; Lancaster, 1987; Khanna, 1980]. The occurrence of welding cracks can be prevented or avoided by using several procedures, such as preheating, postheating, buttering and control of the cooling rate by controlling the size of the weld puddle. However, the use of these procedures is economically considered a loss of time, effort and money, in addition to the difficulty of their use. They may also be inapplicable sometimes depending on the size and shape of the weldment and the welding position [Davies, 1989; WTC, 1983]. Welding cracks can also be prevented or reduced easily with less costs by choosing the appropriate type of the welding electrode used as a filler metal in the manual metal arc (MMA) which is considered one of the most popular process used to weld low alloy steels. There are generally dozens of welding electrodes manufactured specially for the welding of LAHSS which are varied in the chemical composition of their wires and coatings and in their prices as well [ESAB, 2001; Oerlikon, 2002]. LAHSS can be welded with a thickness of $(6 \mathrm{~mm})$ or less using electrodes manufactured of mild steels to obtain tensile strengths of the weld joints approaching to that of the base metals. Higher strength alloys usually require filler metals which have mechanical properties similar to that of the base metal, and cold cracks can be avoided in the LAHSS welds using low hydrogen covering electrodes (manufactured of mild or alloy steels) and low cooling rates [Khanna, 1980]. Jilabi in 2010 investigated the effect of using a range of welding electrodes which are varied in their chemical compositions and their prices on the tensile strength of LAHSS welds, especially, the tensile test is considered the most important non-destructive test at all [Khanna, 1980]. In addition to the tensile strength, the tension test can also be used to determine the yield strength, modulus of elasticity and toughness of the welds. Avazkonandeh-Gharavol et al. studied in 2009 the effect of (0.14-0.94 wt. \%) copper content on the mechanical properties of low alloy Cr-Ni$\mathrm{Cu}$ steel welds deposited by the MMA welding process. The study showed an increase in the 
values of hardness, yield and tensile strengths with a decrease in the impact toughness and elongation values. The effects of copper (0.03 to 0.89 wt. \%), nickel $(0.01$ to 1.54 wt. \%) and boron (36 to $44 \mathrm{ppm}$ ) contents on the mechanical properties of low alloy steel welds deposited by the submerged arc welding process at high heat input $(4.8 \mathrm{~kJ} / \mathrm{mm})$ was studied by Kluken et al. in 1994. The results revealed that the addition of boron at the higher levels of copper and nickel does not improve the mechanical properties at that heat input. In 2008, Moon et al. studied the effect of copper and boron contents on the mechanical properties of the Gleeble simulated CGHAZ of the LAHSS plates. The study showed a decrease in the value of toughness and an increase in the Vickers hardness value with increased copper and boron contents. The current study aims to improve the tensile strength of LAHSS welds using an economical technique which depends on coiling copper wires with different diameters around and along a cheap welding electrode (OK 46.00) in addition to the use of an expensive electrode (OK 73.68) for comparison.

\section{EXPERIMENTAL WORK}

\section{Base Metal}

Table (1) shows the chemical composition, specification symbol, shape and cross section of the raw material used as a base metal according to the Russian specifications (GOST), approved in the State Company for Automotive and Equipment Industries/ Alexandria, the site of the search implementation [(MH), 1978; (MIR), 1968].

\section{Electrodes Used}

Table (2) shows the electrodes used as a filler metal according to the Sweden specifications (OK) [ESAB, 2001; Oerlikon, 2002].

\section{Joints Welding}

Manual metal arc welding of LAHSS has been carried out firstly, by using the cheap electrode (OK 46.00), followed by the use of the same electrode type after coiling pure copper wires (which are used in manufacturing electrical motors) with different diameters $(0.4,0.6,0.8$, $1.0 \mathrm{~mm}$ ) around and along these electrodes (Figure 1). The expensive electrode (OK 73.68) was also used for comparison. Table (3) shows the methods used to weld LAHSS and some welding conditions. The following procedures have been carefully implemented:

1. Removing rust, oils, grease, chips and other impurities from the surfaces of the pieces to be welded.

2. Adjusting the distance between the pieces being welded (root gap) with the suitable value (3.2 $\mathrm{mm})$.

3. Joining the ends of the pieces being welded with small weld beads (tack welds) using the same electrode type used in welding, followed by removing the slag.

4. Welding one side of the weld joint and removing the slag before welding the other side.

\section{Tension Test}

Three tensile specimens from each weldment, in addition to three specimens from the base metal were manufactured according to the American Standards for Testing of Materials [ASTM, 1989]. The specimens were tested using the tension testing machine (Model YMM20) in the State Company for Automotive and Equipment Industries/ Alexandria. The rate of the test results of the three specimens for each weld was calculated to represent the tensile strength of that weld. 


\section{RESULTS AND DISCUSSION}

This type of steel (40XHM) was selected as a base metal for being one of the most difficult LAHSS types to weld due to its high hardenability as a result of its relatively high contents of carbon and alloying elements [Khanna,1980; Lancaster, 1987]. Table (4) shows the tensile test results of this steel's welds. The fracture in all the test specimens was in the weld zone, therefore, the tensile strength values shown in Table (4) represent the tensile strength values of the weld metal of these welds. On the other hand, the tensile test result of the base metal specimens was ( $850 \mathrm{MPa})$, and thus the weld joint efficiency for each weldment can be calculated by the following relationship [Khanna, 1980]:

Weld metal tensile strength

$$
\text { Weld joint efficiency }(\%)=\frac{\text { Base metal tensile strength }}{\text { N }} \times 100
$$

Table (5) and Figure (2) show the weld joint efficiency for each weld.

It is clearly noted from Table (4) that the tensile strength of the weld metal deposited by the MMA welding of LAHSS plates (Table 1) using the (OK 46.00) electrode was (206 MPa). This value is lower than the typical tensile strength of the weld metal $(510 \mathrm{MPa})$ mentioned in Table (2). Table (5) and Figure (2) show that the weld joint efficiency of this weld is also low $(24.2 \%)$. The reason behind these low values is that the (OK 46.00) electrode is specially made for the welding of mild steels and not for the LAHSS welds [ESAB, 2001]. This is because it is a cellulose (high hydrogen) electrode exposing the hardenable steel welds to hot and cold welding cracks, and thus reducing the tensile strength of the welds, in addition to causing the porosity as being a high hydrogen covering electrode [Stuart, 1997; Gray et al., 1975]. This electrode has been used in this study for comparison due to the fact that it is the cheapest and most widely used electrode ever. This is because the electrode coating contains a high proportion of titania and potassium (Table 2) which are easily ionized when heated by the welding arc causing the stability of the arc during welding and the ease of ignition [ASM, 1971].It is also noted from Table (4) that the tensile strength of the weld metal resulting from the use of the (OK 73.68) electrode increased to $(712 \mathrm{MPa})$ which is higher than the typical tensile strength of the weld metal (610 MPa) to which was referred in Table (2). Table (5) and Figure (2) also show that the weld joint efficiency of this weld increased to (83.8\%). This is because the coating of this electrode (specialized for the welding of low alloy steels) has a high proportion of iron powder and it is low in hydrogen too (Table 2). This high proportion of the iron powder which may reach (55\%) increases the deposition rate and thus decreases the dilution ratio avoiding hot cracks in the weld [Stuart, 1997]. In addition, the low hydrogen content of this electrode prevents the occurrence of cold cracks and the porosity of the weld metal [ASM, 1975]. Furthermore, the weld metal deposited by the use of this electrode contains approximately $2.5 \%$ nickel (Table 2 ) which increases the ductility and decreases the brittleness of the weld metal and thus reducing the hot cracks [Gray et al., 1975] which subsequently increases the tensile strength of the weld metal. Despite the relatively high value of the tensile strength of the weld metal resulted by the use of the (OK 73.68) electrode, this electrode is costly and may be unprofitable in the industrial field. So, pure copper wires (which are used in the manufacture of electrical motors) with different diameters $(0.4,0.6,0.8,1.0 \mathrm{~mm}$ ) around and along the cheap electrodes (OK 46.00) have been manually coiled (Figure 1) to be used in the welding of LAHSS plates. The reason behind this is that the copper is a ductile metal which might increase the ductility and decrease 
the brittleness of the weld metal and thus reducing the possibility of hot cracks during the welding of these types of steels. Table (4) shows that the highest tensile strength of the weld metals resulted by the use of the cheap electrodes (OK 46.00) with copper wires was (510 MPa) which is the tensile strength of the weld metal deposited by the use of the $(0.6 \mathrm{~mm})$ dia. copper wire. This value of the tensile strength is about 2.5 times that resulted by the use of the same electrode without coiling copper wires around it, and equals to $(71.63 \%)$ of that resulted by the use of the expensive electrode (OK 73.68). The weld joint efficiency of this weld also increased to (60\%) as shown in Table (5) and Figure (2). Accordingly, coiling copper wires around the cheap electrode (OK 46.00) to be used in the welding of LAHSS plates is considered a successful technique, where a good tensile strength has been obtained with a great reduction in cost. Therefore, this technique is considered profitable in the industrial field.

\section{CONCLUSIONS}

1. The cheap widespread cellulose (high hydrogen) electrode (OK 46.00) is inappropriate for the welding of low alloy high strength steels due to the low tensile strength caused by the use of this electrode.

2. The tensile strength of the weld metal significantly increases when the expensive $2.5 \%$ nickelalloyed iron powder low hydrogen covering electrode (OK 73.68) is used.

3. Coiling a $(0.6 \mathrm{~mm})$ dia. copper wire around the cheap electrode (OK 46.00) notably increases the tensile strength of the weld metal. Consequently, this technique is economically considered successful, by which the weld joint efficiency is greatly increased with a significant reduction in cost.

Table 1: Chemical composition, shape and raw material cross section of the base metal.

\begin{tabular}{|c|c|c|c|c|c|c|c|c|c|c|c|}
\hline \multirow{2}{*}{$\begin{array}{l}\text { Base } \\
\text { metal }\end{array}$} & \multirow{2}{*}{$\begin{array}{c}\text { Spec. } \\
\text { symbol }\end{array}$} & \multirow{2}{*}{$\begin{array}{l}\text { Shape and raw } \\
\text { material cross } \\
\text { section (mm) } \\
\text { (as annealed) }\end{array}$} & \multicolumn{9}{|c|}{ Chemical composition (wt. \%) } \\
\hline & & & $\mathbf{C}$ & Mn & Si & $\mathbf{C r}$ & $\mathbf{N i}$ & Mo & $\mathbf{P}, \mathbf{S}$ & $\mathbf{C u}$ & $\mathrm{Fe}$ \\
\hline $\begin{array}{l}\text { Low alloy } \\
\text { high } \\
\text { strength } \\
\text { steel }\end{array}$ & 40XHM & Plate $(6 * 100)$ & $\begin{array}{c}0.36- \\
0.44\end{array}$ & $\begin{array}{c}0.5- \\
0.8\end{array}$ & $\begin{array}{c}0.15- \\
0.30\end{array}$ & $\begin{array}{c}0.6- \\
0.9\end{array}$ & $\begin{array}{l}1.25- \\
1.75\end{array}$ & $\begin{array}{c}0.15- \\
0.25\end{array}$ & $\begin{array}{l}0.04 \\
\max \end{array}$ & $\begin{array}{l}0.03 \\
\max \end{array}$ & Balance \\
\hline
\end{tabular}

Table 2: Electrodes specifications.

\begin{tabular}{|c|c|c|c|c|c|c|c|c|c|c|c|}
\hline \multirow[b]{2}{*}{ Electrode } & \multirow{2}{*}{$\begin{array}{l}\text { Electrode } \\
\text { type }\end{array}$} & \multirow{2}{*}{$\begin{array}{c}\text { Coating } \\
\text { type }\end{array}$} & \multirow{2}{*}{$\begin{array}{c}\text { Wire } \\
\text { metal type }\end{array}$} & \multicolumn{3}{|c|}{$\begin{array}{c}\text { Typical properties all } \\
\text { weld metal }\end{array}$} & \multicolumn{5}{|c|}{$\begin{array}{l}\text { Typical all weld metal } \\
\text { composition (wt. \%) }\end{array}$} \\
\hline & & & & $\begin{array}{c}\text { Tensile } \\
\text { strength } \\
\text { (MPa) }\end{array}$ & $\begin{array}{l}\text { Yield } \\
\text { stress } \\
\text { (MPa) }\end{array}$ & $\begin{array}{l}\text { El. } \\
(\%)\end{array}$ & C & Mn & $\mathbf{S i}$ & $\mathbf{N i}$ & $\mathbf{F e}$ \\
\hline OK 46.00 & Rutile & $\begin{array}{l}\text { Titania- } \\
\text { Potassium }\end{array}$ & Mild steel & 510 & 400 & 28 & 0.08 & 0.4 & 0.3 & - & Balance \\
\hline OK 73.68 & $\begin{array}{l}2.5 \% \text { nickel- } \\
\text { alloyed } \\
\text { LMA }\end{array}$ & $\begin{array}{c}\text { Iron } \\
\text { powder-low } \\
\text { hydrogen }\end{array}$ & $\begin{array}{l}\text { Low alloy } \\
\text { steel }\end{array}$ & 610 & 520 & 26 & 0.05 & 1.0 & 0.35 & 2.4 & Balance \\
\hline
\end{tabular}


Table 3: Welding conditions.

\begin{tabular}{|c|c|c|c|c|c|c|}
\hline \multirow{2}{*}{ Welding conditions } & \multirow{2}{*}{$\begin{array}{l}\text { OK } 46.00 \\
\text { electrode }\end{array}$} & \multicolumn{4}{|c|}{$\begin{array}{l}\text { OK } 46.00 \text { electrode after coiling a copper } \\
\text { wire with a diameter }(\mathrm{mm})\end{array}$} & \multirow{2}{*}{$\begin{array}{l}\text { OK } 73.68 \\
\text { electrode }\end{array}$} \\
\hline & & 0.4 & 0.6 & 0.8 & 1.0 & \\
\hline Current value (A) & 125 & 125 & 130 & 135 & 140 & 145 \\
\hline Electrode size (mm) & \multicolumn{6}{|c|}{3.2} \\
\hline Current type & \multicolumn{6}{|c|}{$\mathrm{DC}+$} \\
\hline Position & \multicolumn{6}{|c|}{ Flat } \\
\hline
\end{tabular}

Table 4: $\quad$ Tensile test results.

\begin{tabular}{|c|c|c|c|c|c|c|}
\hline \multirow{2}{*}{ Welding by the use of } & \multirow{2}{*}{$\begin{array}{l}\text { OK } 46.00 \\
\text { electrode }\end{array}$} & \multicolumn{4}{|c|}{$\begin{array}{l}\text { OK 46.00 electrode after coiling a copper wire with a } \\
\text { diameter }(\mathrm{mm})\end{array}$} & \multirow{2}{*}{$\begin{array}{l}\text { OK } 73.68 \\
\text { electrode }\end{array}$} \\
\hline & & 0.4 & 0.6 & 0.8 & 1.0 & \\
\hline $\begin{array}{l}\text { Tensile strength } \\
\quad \text { (MPa) }\end{array}$ & 206 & 324 & 510 & 432 & 245 & 712 \\
\hline
\end{tabular}

Table 5: $\quad$ The weld joint efficiency for each weld.

\begin{tabular}{|c|c|c|c|c|c|c|}
\hline \multirow{2}{*}{ Welding by the use of } & \multirow{2}{*}{$\begin{array}{l}\text { OK } 46.00 \\
\text { electrode }\end{array}$} & \multicolumn{4}{|c|}{$\begin{array}{l}\text { OK 46.00 electrode after coiling a copper wire with a } \\
\text { diameter }(\mathrm{mm})\end{array}$} & \multirow{2}{*}{$\begin{array}{l}\text { OK } 73.68 \\
\text { electrode }\end{array}$} \\
\hline & & 0.4 & 0.6 & 0.8 & 1.0 & \\
\hline $\begin{array}{c}\text { Weld joint efficiency } \\
(\%)\end{array}$ & 24.2 & 38.1 & 60.0 & 50.8 & 28.8 & 83.8 \\
\hline
\end{tabular}

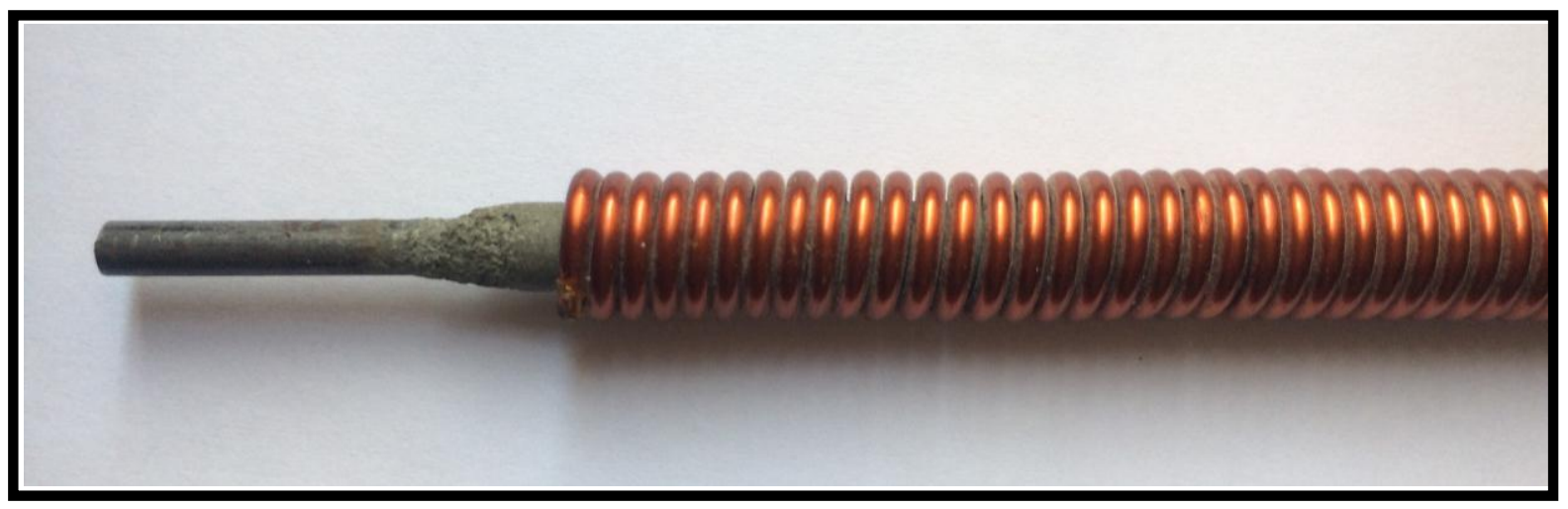

Fig. 1: OK 46.00 electrode around and along which a copper wire was coiled 


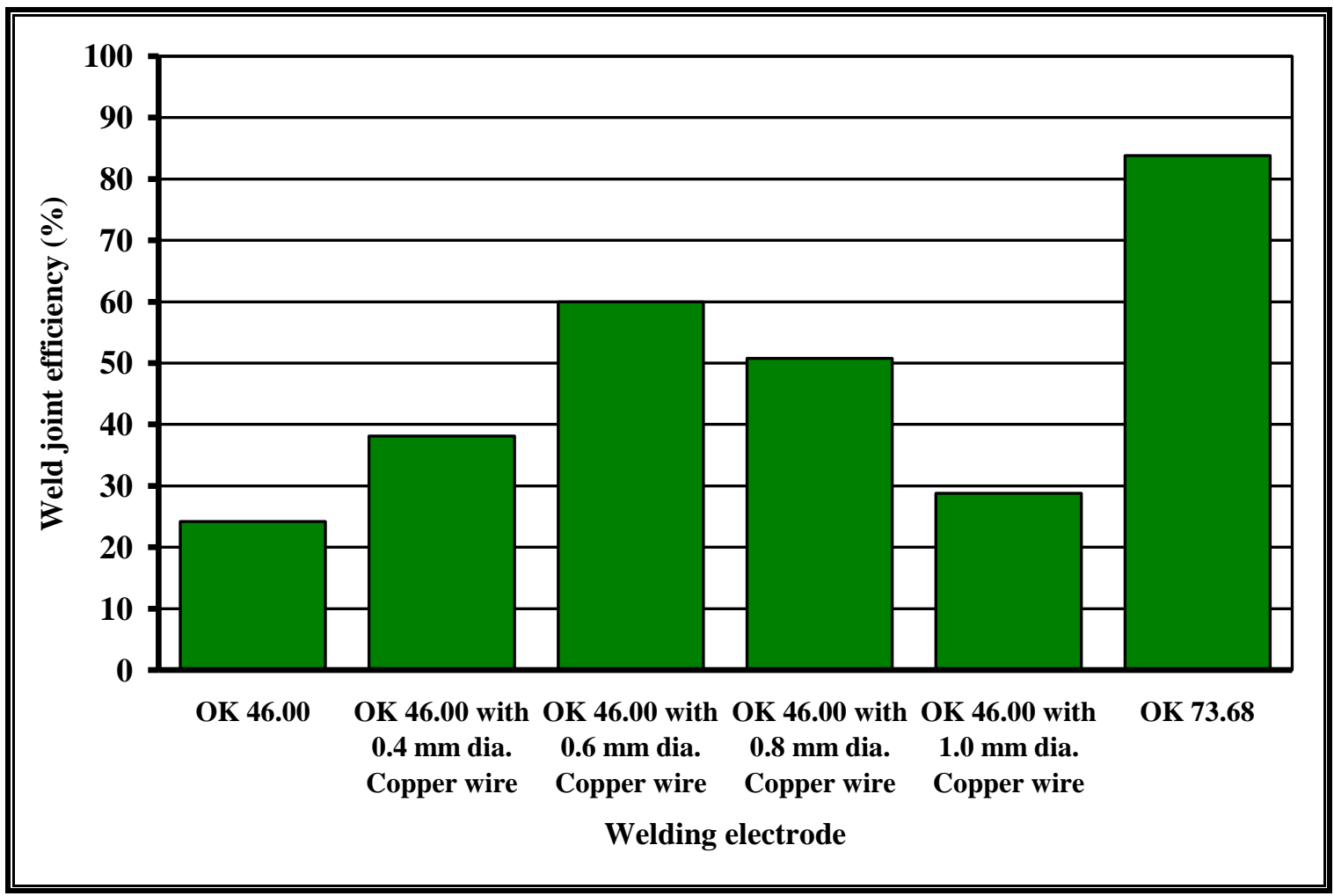

Fig. 2: The weld joint efficiency for each weld.

\section{REFERENCES}

ASM (1975), Failure Analysis and Prevention, Metals Handbook, 18thed.

ASM (1971), Welding and Brazing, Metals Handbook, 8thed.

ASTM (1989), Metals Test Method and Analytical Procedures, vol. 03.01.

Avazkonandeh-Gharavol M.H., Haddad-Sabzevar M. and Haerianb A. (2009), Effect of copper content on the microstructure and mechanical properties of multipass MMA, low alloy steel weld metal deposits, Materials \& Design, 30(6):1902-1912.

Bailey F. W. J. (1972), Fundamentals of Engineering Metallurgy and Materials, SI metric edition, Cassell, London.

Davies A. C. (1989), The Science and Practice of Welding - Vol.1: Welding science and technology; Vol.2: The practice of welding, Cambridge: Cambridge University Press, 9thed.

ESAB (2001), Consumables for manual and automatic welding, Welding Handbook, 6th ed., Sweden.

Gray T. G. F., Spence J. and North T. H. (1975), Rational Welding Design, 79(773):230.

Jilabi A. J. A. (2010), Studying effect of welding electrodes on the tensile strength of low alloy high strength steel weldments, Journal of Babylon University, 18(4). 
Khanna O. P. (1980), Welding Technology, A text Book for Engineering Students, Dhanpat Rai and Sons.

Kluken A. O., Siewert T. A. and Smith R. (1994), Effects of copper, nickel and boron on mechanical properties of low-alloy steel weld metals deposited at high heat input, Welding journal, Welding research supplement, 193-199.

Lancaster J. F. (1987), Metallurgy of Welding, Woodhead publishing limited, Cambridge, England, 6thed.

(MH) (1978), Metallurgy Handbook, Prom Import Raw Material, USSR.

(MIR) Publishers (1968), Metallurgists Handbook, Moscow, 2nded.

Moon J., Kim S., Lee J., Hwang B., Lee C.G. and Lee C. (2008), Effect of Cu and B addition on tempering behavior in the weld CGHAZ of high strength low alloy plate steel, Materials Science and Engineering: A, 497(1-2):153-159.

Oerlikon (2002), Handbook of Welding Consumables, COBISA GmbH Germany.

Stuart W. G. (1997), Advanced Welding, Macmillan Press LDT, Hong Kong.

(WTC) Welding Training Centre (1983), Metallurgical Processes of Arc Welding. 